\title{
Oxidation Ditch Reactor to Remove Ammonia and Phosphate in Tofu Wastewater and Skin Tanning Wastewater
}

\author{
Ni Made Maya Febriana Ramadhany ${ }^{1}$, Savira Safrialia 2, Lolita Kurniasari 2, Iqbal Ramadhan 2, \\ Euis Nurul Hidayah ${ }^{2 *}$, Aulia Ulfa Farahdiba ${ }^{2}$

\begin{abstract}
${ }^{1}$ Department of Enviromental Science, Universitas Pembangunan Nasional “Veteran” Surabaya, East Java, Indonesia

2Department of Enviromental Engineering, Universitas Pembangunan Nasional "Veteran” Surabaya, East Java, Indonesia
\end{abstract}

*Corresponding author:

E-mail: euish.t1@upnjatim.ac.id

\begin{abstract}
Wastewater containing various types of environmental pollutants, for example, Ammonia and phosphate. Wastewater disposal without proper handling will have an impact on environmental quality degradation, so it is necessary to wastewater treatment using an oxidation ditch reactor with a capacity of 500 liters with an operational volume of 250 liters. The variation treatment in this study was by using tofu wastewater $(\mathrm{T})$ and skin tanning wastewater $(\mathrm{PK})$ with direct sunlight and aeration process with $60 \mathrm{rpm}$ rotation speed for 24 hours $\mathrm{x} 7$ days. The results showed (T) was able to reduce the ammonia concentration by $94.1 \%$ from a value of $0.18 \mathrm{mg} / \mathrm{L}$ to $0.07 \mathrm{mg} / \mathrm{L}$ and a phosphate concentration of $75.3 \%$ from a value of $16.05 \mathrm{mg} / \mathrm{L}$ to $3.96 \mathrm{mg} / \mathrm{L}$. Whereas the $(\mathrm{PK})$ able to reduce the ammonia concentration by $94.1 \%$ from a value of $0.18 \mathrm{mg} / \mathrm{L}$ to $0.07 \mathrm{mg} / \mathrm{L}$ and a phosphate concentration of $41.4 \%$ from a value of $10.2 \mathrm{mg} / \mathrm{L}$ to $5.9 \mathrm{mg} / \mathrm{L}$.
\end{abstract}

Keywords: oxidation ditch reactor, wasterwater, ammonia, phosphate

\section{Introduction}

Every stage in industrial processing generally uses relatively large amounts of water (GerbensLeenes et al., 2013). The final process of industrial activities can also produce wastewater which contains many organic compounds such as ammonia and phosphate. Tofu and skin tanning industrial wastewater contains high levels of organic materials in the form of protein, carbohydrates, fats, oils, and amino acids (Nurhasan \& Pramudyanto, 1997). The presence of these organic compounds causes industrial wastewater to contain high ammonia and phosphorus which, if discharged into the water without prior treatment, can cause pollution (Husin, 2003;Akpor et al., 2014).

Most of the tofu and tanning industry still do not have wastewater treatment, so that industrial entrepreneurs dispose of their wastewater into water bodies which if it exceeds the carrying capacity of the environment it can reduce the quality of the environment (Nurhasan, 1997).

Based on these considerations, the oxidation ditch reactor is one way that can be used to treat industrial process wastewater that is environmentally friendly (Alaya et al., 2010). This reactor consists of a series of reactor that aims to purify wastewater so that it is not harmful to the environment. The advantages of this technology in wastewater treatment are simple construction, easy to design, and can continue to function even though the various types of waste, such as livestock waste, household waste, and other domestic waste, produce algae containing high protein, which can be utilized for fisheries and maintenance costs are relatively cheap (Abdel-Shafy \& Mansour, 2018; Jayashree et al., 2014).

\section{How to cite:}

Ramadhany, N. M. M. F., Safrilia, S., Kurniasari, L., Ramadhan, I., Hidayah, E. N., \& Farahdhiba, A. U. (2020). Oxidation ditch reactor to remove ammonia and phosphate in tofu wastewater and skin tanning wastewater. $1^{\text {st }}$ International Conference Eco- Innovation in Science, Engineering, and Technology. NST Proceedings. pages 102-106. doi: 10.11594/ nstp.2020.0515 
The purpose of this study was to determine the effectiveness of the oxidation ditch reactor as tofu and tanning industrial wastewater treatment reactor. Therefore, it is necessary to treat wastewater that is a low cost, environmentally friendly, and has good potential.

\section{Research Method}

\section{Research time and location}

This research was conducted by direct exposure on a customized rooftop in Surabaya. Every parameter is analyzed at Balai Riset dan Standardisasi Industri Surabaya (Baristand).

\section{Experimental Setup}

This experimental setup was designed to set aside any organic materials. These parameters which would be planned to be researched were ammonia and phosphate. Aeration is carried out in Oxidation Ditch with an aerator brush mounted on the reactor. Testing is carried out every day for 7 days on a laboratory scale in reactors with tofu wastewater and tanning wastewater. This study conducted using 2 types of water wastewater. The first study used tofu wastewater was taken from tofu's industrial from the Sidoarjo. The second study used skin tanning wastewater taken from the skin tanning industrial from the Magetan.

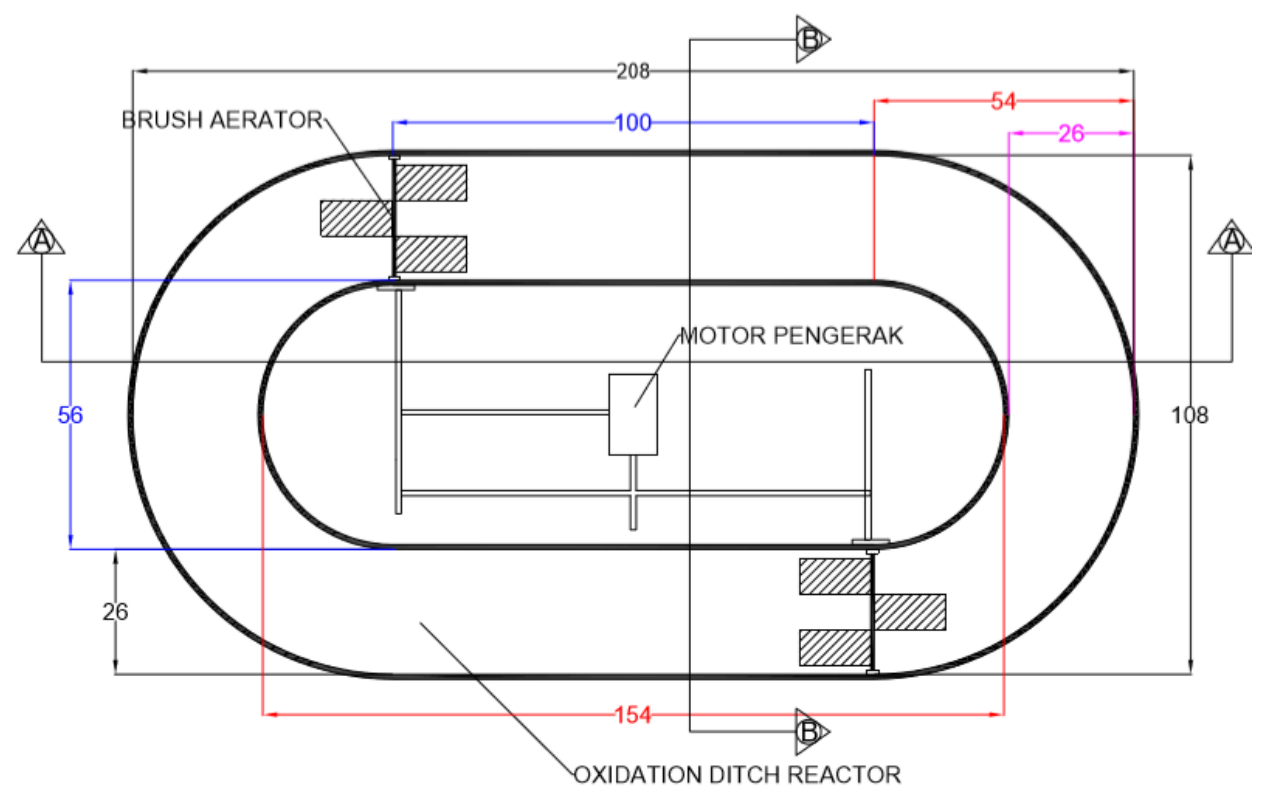

Figure 1. Design of oxidation ditch reactor

The research was conducted using an oxidation ditch reactor with design can be seen in Figure 1 and Figure 2 the reactor used has a capacity of 500 liters with an operational volume of 250 liters with an aerator rotation of 60 revolutions per minute $(\mathrm{rpm})$ with a batch system and direct sunlight. The reactor is equipped with a stirrer to increase the flow velocity and turbulence obviate algae to submerge. Phosphate analysis refers to SNI 06-6989.31-2005 by spectrophotometer with ascorbic acid. Ammonia (NH3) refers to SNI 06-6989.30-2005 with a phenolic by spectrophotometer. 


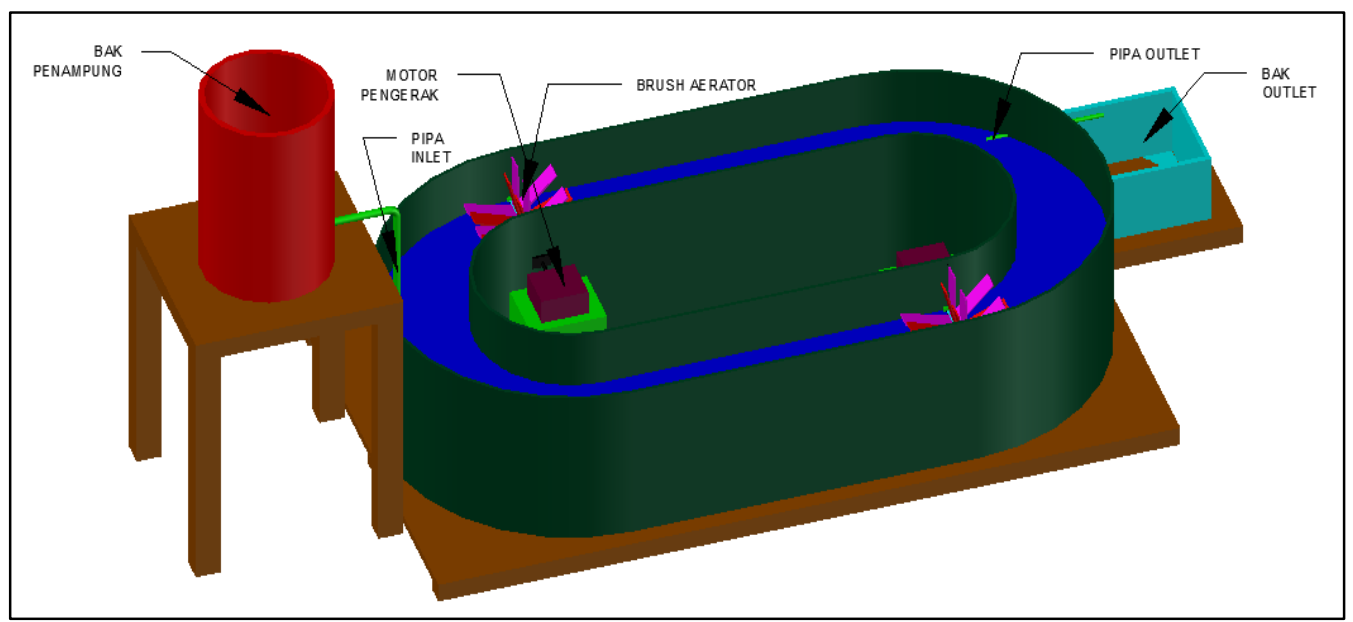

Figure 2. Oxidation ditch reactor 3D

\section{Results and Discussion \\ Removal of ammonia $\left(\mathrm{NH}_{3}\right)$}

The oxidation ditch reactors with tofu wastewater have lower ammonia residues compared to skin tanning wastewater. These differences could occur because the type of wastewater and the concentration of wastewater used were different. The decline occurred on the first day to the last day. The highest reduction of these both waste (tofu and skin tanning) was on the second day. This equation could occur in the same kind of environment and treatment as well. To decrease the results of the analysis of the value of ammonia (NH3) can be seen from Figure 3 and Figure 4.

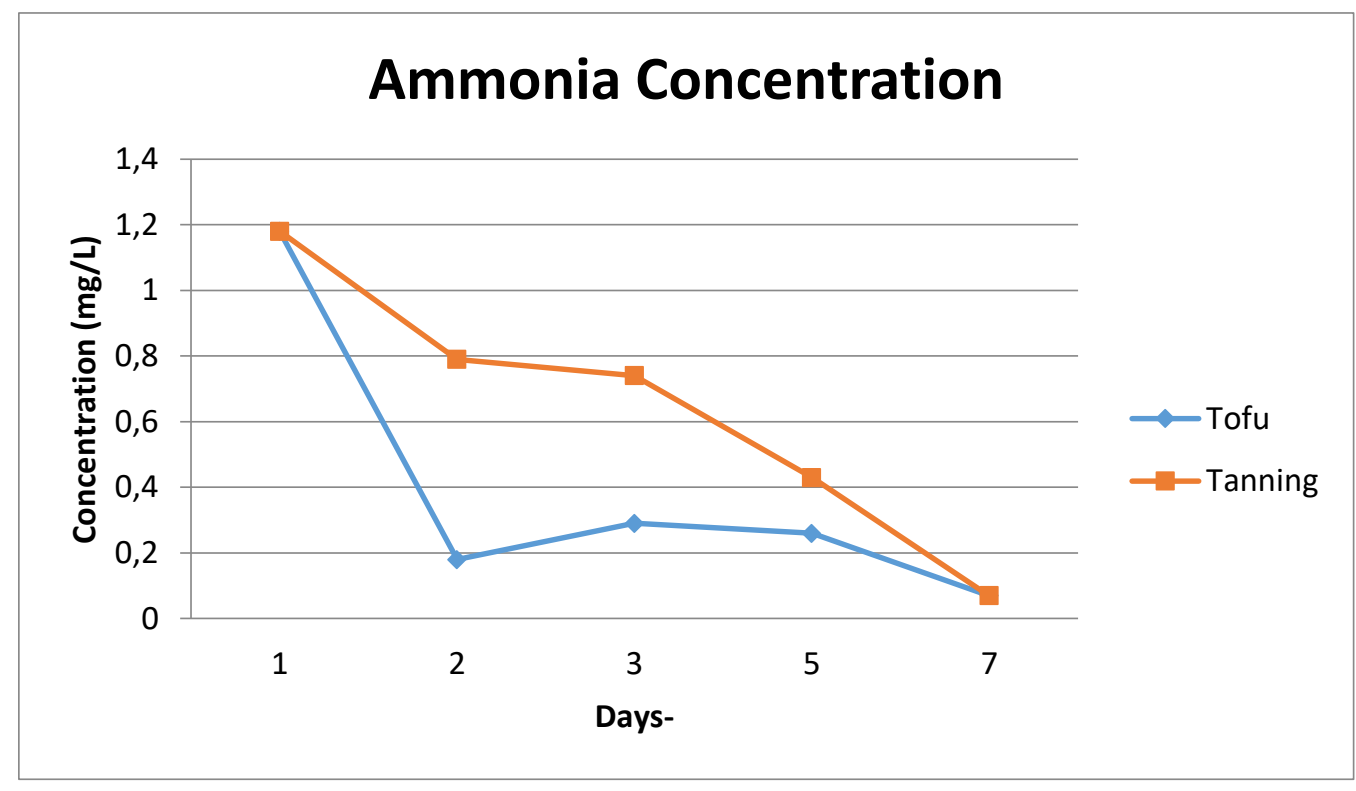

Figure 3. Ammonia Concentration in oxidation Ditch Reactor 


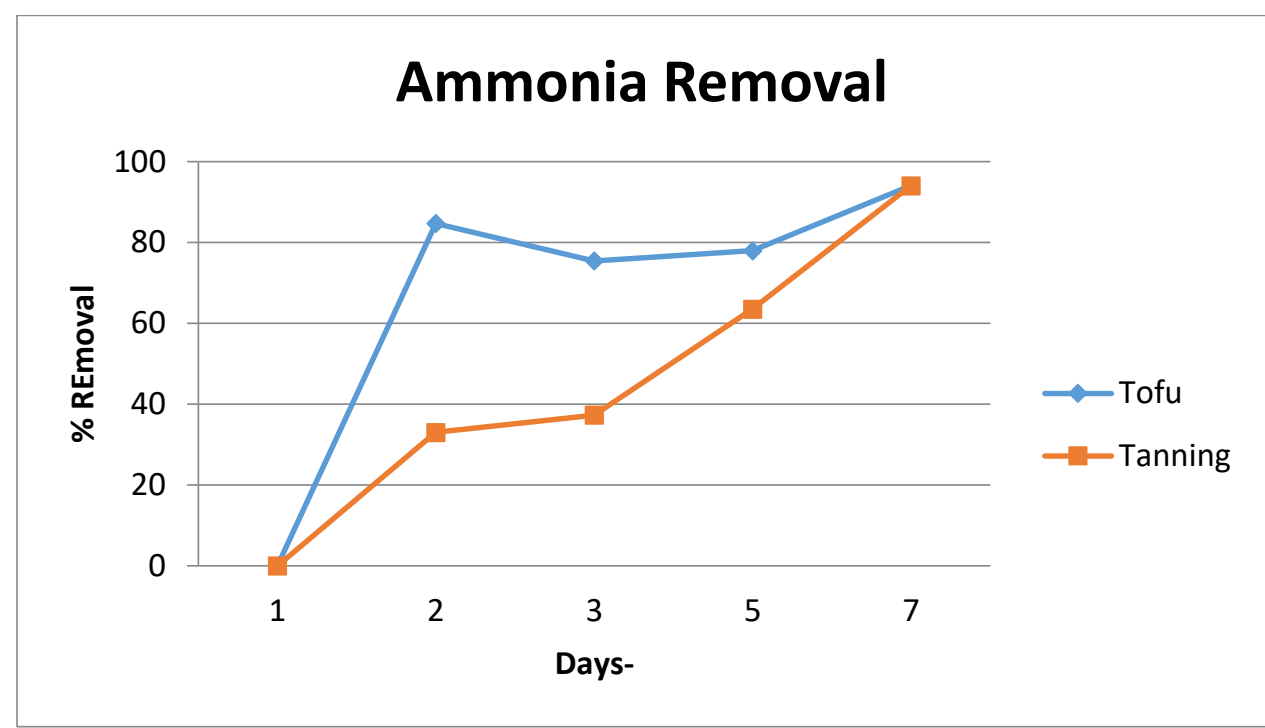

Figure 4. Performance of ammonia removal in oxidation ditch reactor

This shows that in each reactor the ammonia degradation process (NH3). This could explain that tofu wastewater can reduce the concentration of ammonia far more than skin tanning wastewater by using an oxidation ditch reactor

\section{Removal of phosphate $\left(\mathrm{PO}_{4}\right)$}

The oxidation ditch reactors with skin tanning wastewater have lower ammonia residues compared to tofu wastewater. These comparisons could happen due to both types of wastewater and wastewater concentration which are quite different. The reductions happened from the first to the last day. These phenomenons reached its higher state in tofu wastewater on the seventh day (last day), yet skin tanning wastewater went into a relatively constant decline. These comparisons could happen due to their different wastewater concentration. Figure 5 and figure 6 , are shown the performance of phosphate in the oxidation ditch reactor.

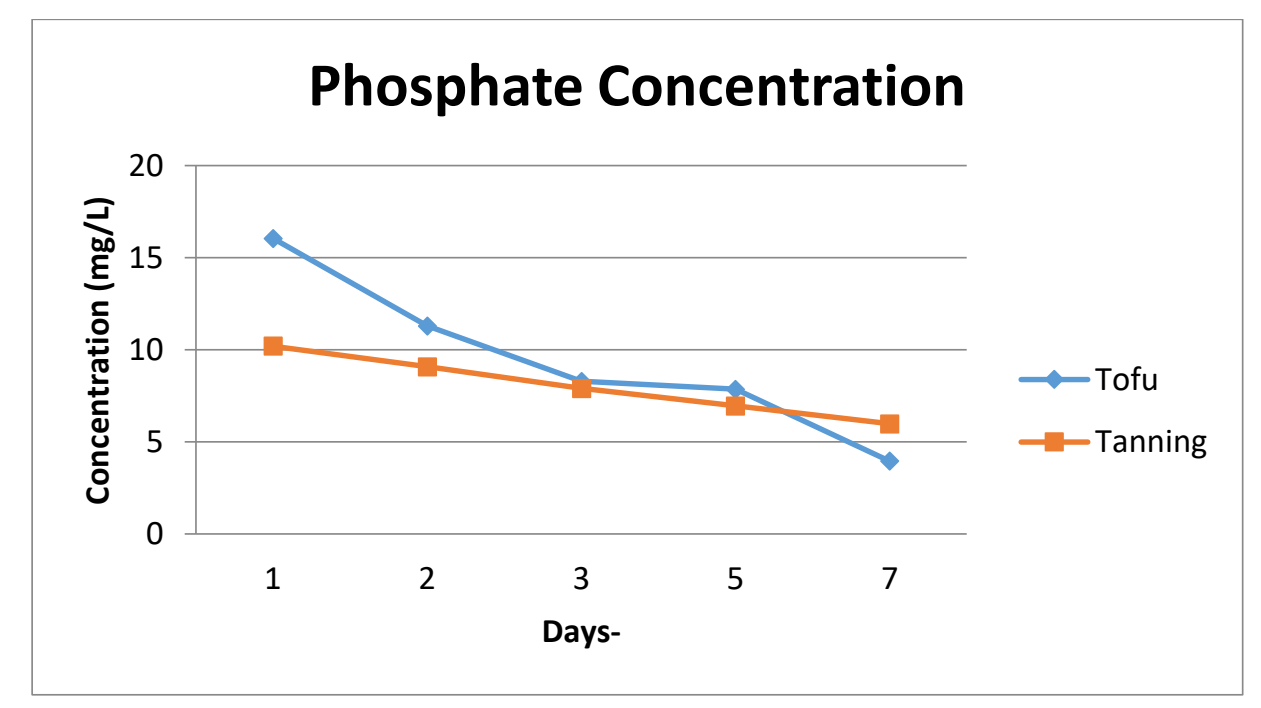

Figure 5. Phosphate concentration in oxidation ditch reactor 


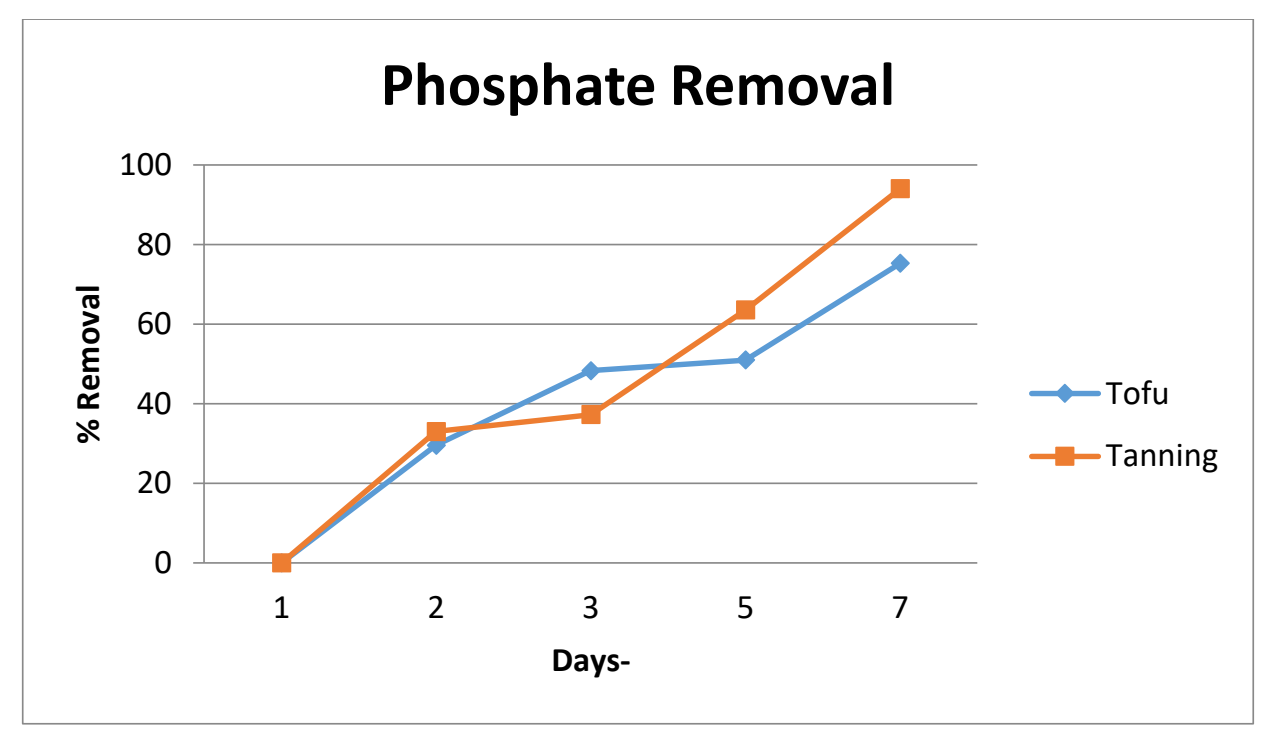

Figure 6. Performance of phosphate removal in oxidation ditch reactor

\section{Conclusion}

Research shows the ability of Oxidation Ditch Reactor to reduce levels of ammonia (NH3) and phosphate (PO4) in tofu wastewater $94,1 \%$ and $75,3 \%$ to respectively, while skin tanning wastewater $94,1 \%$ and $41,4 \%$. By using Oxidation Ditch Reactor, this method could set aside far more ammonia in skin tanning wastewater rather than inside tofu wastewater. However its capability, with tofu wastewater, far more phosphate than its application in skin tanning wastewater.

\section{Acknowledgment}

Great appreciation for research funding is delivered to Kementerian Riset, Teknologi dan Pendidikan Tinggi, Indonesia for scheme $2^{\text {nd }}$ year of Basic Research with contract no. 086/SP2H/LT/DRPM/2019.

\section{References}

Abdel-Shafy, H., \& Mansour, M. S. M. (2018). Solid waste issue: Sources, composition, disposal, recycling, and valorization.Egyptian Journal of Petroleum, 27(4), 1275-1290. https://doi.org/10.1016/j.ejpe.2018.07.003

Akpor, O., Otohinoyi, D. A., Olaolu, T. D., Aderiye, J. B. I. (2014). Pollutants in wastewater effluents: Impacts and remediation processes. Enviromental Microbiology, 3(3), 050-059.

Alaya, S. B., Haouech, L., Cherif, H., \& Shayeb, H. (2010). Aeration management in an oxidation ditch. Desalination, 252(1), 172-178. doi: 10.1016/j.desal.2009.11.001.

Gerbens-Leenes, P. W., Mekonnen, M. M., \& Hoekstra, A. Y. (2013). The water footprint of poultry, pork and beef: A comparative study in different countries and production systems. Water Resources and Industry, 1-2, 25-36.

Husin, A. (2003). Pengolahan Limbah Cair Industri Tahu Menggunakan Biji Kelor (Moringa Oleifera) Sebagai Koagulan." Laporan penelitian Dosen Muda Fakultas Teknik Universitas Sumatra Utara, 2003.

Jayashree, D., Arvind, C., Sangita, I. (2014). Design of laboratory based waste water treatment plant. Int. Res. J. of Science \& Engineering, 2(3), 104-111.

Nurhasan, A., and B. B. Pramudyanto. "Pengolahan Air Buangan Tahu." Semarang: Yayasan Bima Karta Lestari dan Wahana Lingkungan Hidup Indonesia, 1997. 